\title{
MENINGKATKAN HASIL BELAJAR KOORDINASI GERAK MELALUI MODEL KOOPERATIF
}

\author{
Mardiani \\ SDN 18/IX Muaro Jambi \\ Email: mmardiani249@gmail.com
}

\begin{abstract}
This study aims to improve learning outcomes motion coordination through the cooperative model of students of class III Elementary School No. 18 / IX Muaro 2018/2019 academic year the research method is classroom action research, consists of two cycles each cycle carried out 3 times a meeting, each cycle consisting of planning, action, observation and reflection, The research subjects were 26 students in class III, 13 male and 13 female students, data collection techniques are observation, and formative tests, data analysis is comparing the average score, the successful evaluation is KKM of 68 individuals and $80 \%$ classical, The results showed that the pre-cycle completeness of three students or by $12 \%$ increased to 14 students or by $54 \%$ in the first cycle and increased again to 22 or by $85 \%$ in the second cycle, Observation of teacher activity by $68 \%$ in the category of "Good" increased to $83 \%$ in the category of "Very Good" Observation of student activity by $60 \%$ in the category of "Good" increased to $83 \%$ in the category of "Very good" therefore, it can be concluded that the cooperative model improves learning outcomes for the coordination of class III motion elementary school number 18 / IX Muaro Jambi in 2018/2019 academic year.
\end{abstract}

Keywords: cooperative model, learning outcomes, motion coordination.

\begin{abstract}
Abstrak
Penelitian ini bertujuan untuk meningkatkan hasil belajar koordinasi gerak melalui model kooperatif peserta didik kelas III SDN 18/IX Muaro Jambi Tahun Ajaran 2018/2019, metode penelitian dengan Penelitian Tindakan Kelas terdiri dari dua siklus masing-masing siklus dilakukan 3x pertemuan. Subjek penelitian kelas III berjumlah 26 peserta didik 13 putra dan 13 putri.Teknik pengumpulan data yaitu lembar observasi, dan tes formatif, analisis data yaitu membandingkan rata-rata skor, kriteria keberhasilan yaitu KKM sebesar 68 individu dan 80\% klasikal. Hasil penelitian menunjukkan bahwa ketuntasan pra siklus sebanyak 14 peserta didik atau 54\% pada siklus I dan meningkat menjadi 22 atau $85 \%$ pada siklus II, observasi aktivitas guru 68\% kategori "Baik" meningkat menjadi 83\% kategori "Sangat Baik" observasi aktivitas peserta didik 60\% kategori "Baik" meningkat menjadi 83\% kategori "sangat baik". Jadi, dapat disimpulkan model kooperatif meningkatkan hasil belajar koordinasi gerak peserta didik kelas III SDN 18/IX Muaro Jambi Tahun Ajaran 2018/2019.
\end{abstract}

Kata Kunci: model kooperatif, hasil belajar, koordinasi gerak. 


\section{PENDAHULUAN}

Pelajaran pendidikan jasmani dan kesehatan ditingkat satuan dasar tidak hanya berorientasi pada kesehatan dan kebugaran jasmani semata namun merupakan satu kesatuan yang tidak dapat dipisahkan dari orientasi pendidikan secara keseluruhan sebagaimana Badan Standar Nasional Pendidikan (BSNP, 2006) menyatakan bahwa muatan aspek dalam pendidikan jasmani tingkat Sekolah Dasar merupakan aspek-aspek yang terpadu dari serangkaian pendidikan dimana keseluruhan muatan pada pendidikan jasmani tidak hanya berbicara tentang kebugaran dan keterampilan gerak akan tetapi juga meliputi keterampilan berfikir kritis, keterampilan sosial, penalaran, stabilitas emosional, tindakan moral dan aspek pola hidup sehat.

Bertolak dari pernyataan tersebut mengindikasikan pentingnya Pendidikan jasmani dan Kesehatan di sekolah, namun pada prosesnya keadaan yang tidak sesuai harapan juga tidak dapat dipisahkan dari sebuah pencapain tujuan, hal-hal yang menyebabkan turunnya tingkat ketercapaian tujuan merupakan polemik tersendiri untuk dicarikan penyelesaiannya.

SDN 18/IX Muaro jambi merupakan salah satu sekolah yang merealisasikan Pendidikan jasmani dan Kesehatan yang kemudian dikemas dalam pelajaran penjaskes pada kenyataannya masih saja ditemui berbagai kendala dalam pencapaian tujuan pelajaran.

Penelitian ini berawal dari kesenjangan yang terjadi dilapangan yaitu masih banyaknya peserta didik yang belum mencapai KKM yang ditetapkan, peneliti sendiri sebagai guru penjaskes awalnya mengira proses pembelajaran berjalan tanpa kendala tapi baru kemudian peneliti sadari bahwa hasil belajar di kelas III yang saat ini masih menerapkan kurikulum KTSP pada pembahasan tentang koordinasi gerak kaki dan tangan serta jalan kayang hasil belajar peserta didik secara umum masih sangat jauh dari KKM yaitu dari 26 peserta didik hanya sebanyak tiga peserta didik atau $12 \%$ yang tuntas selebihnya 23 peserta didik atau $88 \%$ dinyatakan belum tuntas, untuk KKM penjaskes sendiri sekolah menetapkan 
sebesar 68 ketuntasan individual dan $80 \%$ tuntas secara klasikal.

Peneliti terus menggali informasi, melakukan identifikasi masalah dengan cara melakukan pengamatan langsung dan wawancara untuk mengetahui apa yang menjadi penyebab timbulnya masalah, baru kemudian terungkap melalui sesi wawancara bersama sejumlah peserta didik bahwa pelajaran koordinasi gerak kaki dan tangan serta jalan kayang merupakan pelajaran yang membosankan karena dirasa gerakannya tidak mengasikkan, gerakannya tidak mengenakkan, lebih enak dan suka langsung melakukan permainan daripada harus melakukan koordinasi gerakan yang benar,

Berdasarkan hasil pengamatan juga terlihat bahwa peserta didik lebih menyukai permainan pada kelompok kelompok kecil yang terdiri dari dua dan tiga peserta didik daripada berelaborasi dengan kelompok yang lebih besar, peserta didik terlihat cepat bosan dan kurang percaya diri ketika melakukan sejumlah permainan yang melibatkan banyak anggota, peserta didik lebih cenderung banyak termenung dan menunggu perintah daripada melakukan sejumlah inisiatif gerakan bebas yang umumnya dilakukan peserta didik lainnya.

Setelah peneliti mengetahui isuisu yang dihadapi peserta didik segera peneliti merapat kepada guru senior untuk mendengar pengalaman belajar yang mungkin dapat dijadikan referensi disamping semakin aktif mengikuti kegiatan keprofesian dalam upaya menambah khasanah keilmuan yang mungkin dapat dipergunakan untuk mengatasi kesenjangan yang ada.

Berbagai pertemuan tidak membuahkan hasil yang mantap untuk dipergunakan mengatasi isu yang ada karena masing-masing alternatif solusi memiliki kelebihan dan kekurangan tersendiri yang ketika dicermati dengan teliti terdapat tiga hal penting yang perlu dipertimbangkan yakni karakteristik alternatif solusi, (2) karakteristik peserta didik dan (3) situasi sekolah, kemudian setelah peneliti memasuki kajian pustakaan dan literatur pendukung yang relevan akhirnya peniliti menemukan model kooperatif menjadi alternatif yang 
dianggap tepat untuk diaplikasikan dalam upaya mengatasi kesenjangan yang ada.

Pemilihan model kooperatif didasari pertimbangan kesesuaian karakteristik model kooperatif dengan permasalahan yang terjadi, karakteristik peserta didik dan keadaan sekolah, Sejalan dengan itu (Rusman, 2011: 203) menyatakan bahwa dalam pembelajaran berbasis model kooperatif suasana pembelajaran tidak selalu dari guru ke peserta didik akan tetapi menciptakan suasana pembelajaran yang kondusif dari peserta didik ke peserta didik. Lebih lanjut Slavin, dkk (2009: 227) menyatakan bahwa pada prosesnya pembelajaran dengan penerapan model kooperatif suasana pembelajaran dibuat dalam bentuk kelompok-kelompok kecil yang terdiri dari $4-5$ peserta didik.

Beberapa peneliti muktahir yang menunjukkan keefektifan model kooperatif diantaranya Riandini, B,K dan Muhammad, H, N (2013: 334 336) penelitian dengan jenis penelitian tindakan kelas dengan tujuan untuk mengetahui seberapa besar peningkatan hasil belajar passing bawah menggunakan model pembelajaran kooperatif melalui permainan bolavoli mini dalam studi penjasorkes di kelas VIII D SMP N 2 Kandangan Kediri hasil penelitian menunjukkan bahwa implementasi model kooperatif dapat meningkatkan hasil belajar peserta didik. Selanjutnya penelitian sejenis dilakukan oleh Juniarta, dkk (2017: 11 - 22) penelitian dengan fokus meningkatkan aktivitas dan hasil belajar peserta didik melalui penerapan model kooperatif, dilakukan pada Tahun Ajaran 2016/2017 hasil penelitian menunjukkan bahwa model kooperatif dapat meningkatkan aktivitas dan hasil belajar peserta didik.

Berdasarkan latarbelakang masalah, jika masalah tersebut dibiarkan cenderung akan mengakibatkan rendahnya mutu proses dan hasil belajar yang dengan sendirinya akan berimbas pada kualitas dan mutu pendidikan secara keseluruhan.

Tujuan penelitian ini yaitu untuk mengetahui bagaimana model kooperatif dapat meningkatkan hasil 
belajar koordinasi gerak peserta didik kelas III SDN 18/IX Muaro Jambi Tahun Ajaran 2018/2019.

\section{METODE PENELITIAN}

Penelitian ini menggunakan metode Tindakan (Action Research) dengan jenis penelitian tindakan kelas (Classroom action research). (Aqib, Z \& Amrullah, A, 2018: 15-16) menyatakan bahwa PTK menekankan pada tindakan tertentu untuk meningkatkan kualitas proses dan hasil belajar melalui serangkaian prosedur kegiatan yaitu perencanaan tindakan, pelaksanaan tindakan, observasi, interpretasi dan analisis serta refleksi. Selanjutnya Suharsimi, A. (2015:92) menyatakan bahwa defenisi kelas dalam kata penelitian tindakan kelas tidak terikat pada suatu ruangan kelas akan tetapi lebih spesifik kepada sekelompok peserta didik yang melakukan pembelajaran dari dan oleh guru yang sama di dalam atau diluar ruangan pada waktu yang sama pula.

Lokasi penelitian yaitu SDN 18/IX Muaro Jambi yang dilakukan pada semester II Tahun Ajaran 2018/2019 di kelas III terdiri dari 13 putra dan 13 putri. Penelitian ini terdiri dari dua siklus, masing-masing siklus dilakukan $3 \mathrm{x}$ pertemuan dan tiap pertemuan dilakukan selama $3 \mathrm{x}$ 45 menit jam pelajaran, pertemuan pertama dilakukan di dalam kelas yaitu penyampaian pembelajaran secara teoritis tentang koordinasi gerak kaki dan tangan serta jalan kayang dengan menerapkan model kooperatif diikuti observasi aktivitas guru dan aktivitas peserta didik.

Pertemuan ke dua dilakukan diluar kelas yaitu lapangan olahraga SDN 18/IX Muaro Jambi dengan melakukan latihan praktik koordinasi gerak kaki dan tangan serta jalan kayang diikuti observasi aktivitas guru dan aktivitas peserta didik, di akhir latihan diberikan tes praktik untuk mengukur ketepatan peserta didik melakukan gerakan.

Pertemuan ketiga dilakukan di dalam kelas yaitu evaluasi tes formatif untuk mengukur pemahaman peserta didik secara teoritis. Serangkaian kegiatan melewati siklus berdaur yang masing-masing siklus terdiri dari rencana Tindakan, pelaksanaan Tindakan, observasi / pengamatan dan refleksi. Alat 
pengumpul data yang digunakan yaitu lembar observasi, tes formatif dan tes praktik.

Analisis data untuk menentukan ketuntasan belajar yaitu dengan cara menjumlahkan $40 \%$ hasil tes formatif dan $60 \%$ hasil tes praktik dengan ketentuan tuntas menggunakan rumus:

$$
\mathrm{KK}=\frac{N}{s t} x 100
$$

Keterangan:

KK : Ketuntasan klasikal

$\mathrm{N}$ : Jumlah peserta didik yang tuntas

ST : Jumlah peserta didik seluruhnya.

Hamdi, M (2018: 148)

Sedangkan rumus yang digunakan untuk menganalisis hasil observasi yaitu menggunakan rumus:

Presentase nilai rata-rata

$$
(\mathrm{NR})=\frac{\text { Jumlah } \text { Skor }}{\text { Jumlah Maksimal }} \times 100 \%
$$

Adapun kriteria keberhasilan yang digunakan dalam penelitian ini yaitu:

a. Secara hasil belajar peserta didik mencapai KKM sebesar $68 ;$

b. Ketuntasan klasikal sebesar $80 \%$.

Selanjutnya untuk memudahkan interpretasi data menggunakan kriteria penilaian kategori rata-rata seperti pada tabel 1 di bawah ini

Tabel 1. Kriteria penilaian kategori rata-rata

\begin{tabular}{cc}
\hline Interval Nilai & Kategori \\
\hline $80,00-100,00$ & Sangat Baik \\
\hline $70,00-79,99$ & Baik \\
\hline $60,00-69,99$ & Cukup \\
\hline $50,00-59,99$ & Kurang \\
\hline$<50,00$ & Sangat Kurang \\
\hline
\end{tabular}

Berikutnya untuk menafsirkan data hasil persentase menggunakan kategori seperti pada tabel 2 di bawah ini

Tabel 2. Tolok ukur Kategori Persentase

\begin{tabular}{cc}
\hline Persentase & Kategori \\
\hline $75,01-100,00$ & Sangat Baik \\
\hline $50,01-75,00$ & Baik \\
\hline $25,01-50,00$ & Cukup \\
\hline $00,00-25,00$ & Kurang \\
\hline
\end{tabular}

\section{HASIL DAN PEMBAHASAN}

\section{Pra Siklus}

Kegiatan pada tahap pra siklus dilakukan Dengan tujuan untuk mengetahui kondisi awal ketuntasan belajar peserta didik yang merupakan titik tolak dilakukannya penelitian ini, Adapun ketuntasan belajar peserta didik kondisi awal yaitu: rata-rata kelas 55,65 yang berada pada interval dengan kategori "Kurang" dari 26 peserta didik hanya tiga peserta didik atau $12 \%$ yang tuntas sedangkan selebihnya 23 peserta didik atau $88 \%$ 
berikutnya belum tuntas, nilai yang dilakukan peneliti diantaranya: tertinggi 69 dan nilai terendah 50 .

\section{Siklus I}

Siklus I dilakukan sebanyak 3 kali pertemuan yaitu 3x45 menit jam pelajaran pertemuan pertama dilakukan pada hari Sabtu, 9 Februari 2019 dilakukan di dalam kelas yaitu penyampaian materi secara teoritis tentang koordinasi gerak kaki dan tangan serta jalan kayang menggunakan model kooperatif.

Pertemuan kedua dilakukan pada hari Sabtu, 16 Februari 2019 yang dilakukan di lapangan olahraga SDN 18/IX Muaro Jambi yaitu demonstrasi dan praktik latihan koordinasi gerak.

Pertemuan ketiga dilakukan pada hari Sabtu, 23 Februari 2019 yang dilakukan di dalam kelas yaitu penjaringan evaluasi belajar.

\section{Perencanaan Tindakan}

Pada tahap ini peneliti melakukan serangkaian kegiatan dalam upaya merencanakan pelaksanaan tindakan siklus I, hal-hal Melakukan konsultasi dengan kepala sekolah sekaligus memohon izinnya untuk melakukan penelitian, menyiapkan skenario pembelajaran dengan model kooperatif yang dituangkan ke dalam RPP, menyiapkan instrument penelitian, yaitu lembar observasi dan tes formatif, memeriksa berbagai perlengkapan olahraga yang dibutuhkan, menyiapkan perlengkapan $\mathrm{P} 3 \mathrm{~K}$, memastikan kesediaan kepala sekolah dan satu orang guru penjas SDN 104/IX Kedemangan untuk berkenan menjadi kolaborator penelitian sebagai pengamat.

Penyusunan indikator aktivitas guru dan aktivitas peserta didik yaitu dengan memerhatikan keselarasan dan ciri khas model kooperatif serta tujuan pembelajaran, indikator aktivitas guru terdiri dari 15 (limabelas) indikator yang dapat dilihat pada tabel 3 di bawah ini. 
Tabel 3. Indikator Aktivitas Guru

\begin{tabular}{cl}
\hline $\begin{array}{c}\text { No } \\
\text { Item }\end{array}$ & Aktivitas Guru \\
\hline A & KEGIATAN AWAL (3) \\
\hline 1 & Menyampaikan tujuan mempelajari koordinasi gerak \\
\hline 2 & $\begin{array}{l}\text { Apersepsi pelajaran sebelumnya dan mengaitkan dengan pelajaran } \\
\text { koordinasi gerak }\end{array}$ \\
\hline 3 & Memotovasi peserta didik untuk tertarik mengikuti pelajaran \\
\hline B & KEGIATAN INTI (9) \\
\hline 1 & Melakukan tanya jawab seputar materi koordinasi gerak \\
\hline 2 & Membentuk peserta didik beberapa kelompok heterogen (4 - 5 Anggota) \\
\hline 3 & Menjelaskan tugas kelompok, dan anggota kelompok \\
\hline 4 & $\begin{array}{l}\text { Menjelaskan dan memberikan contoh melakukan koordinasi gerak yaitu } \\
\text { koordinasi gerak kaki dan tangan dan jalan kayang }\end{array}$ \\
\hline 5 & $\begin{array}{l}\text { Memberikan penguatan kembali bahwa kerjasama yang baik dalam } \\
\text { kelompok akan menyumbang keberhasilan yang besar }\end{array}$ \\
\hline 6 & Memberikan reward berupa pujian kepada peserta didik yang berhasil \\
\hline 7 & Memberikan support kepada peserta didik yang belum berhasil \\
\hline 8 & $\begin{array}{l}\text { Memberikan kesempatan kepada peserta didik untuk bertanya hal-hal } \\
\text { yang belum dimengerti }\end{array}$ \\
\hline 9 & Membimbing peserta didik yang kesulitan melakukan praktik \\
\hline C & KEGIATAN AKHIR (3) \\
\hline 1 & Membuat kesimpulan pembelajaran \\
\hline 3 & Menutup Pembelajaran \\
\hline & Ketepatan waktu \\
\hline 2
\end{tabular}

Sedangkan indikator aktivitas peserta didik terdiri dari 10 (sepuluh) indikator diantaranya:

Mendengarkan penjelasan dan petunjukan guru dengan tertib; (2) Konsentrasi dengan pembelajaran yang diikuti; (3) Semangat mengikuti pelajaran dengan model kooperatif; (4) Berinteraksi dengan baik dalam kelompok; (5) Menyesuaikan diri dengan kelompok; (6) Saling memotivasi sesama anggota kelompok; (7) Menghargai pemimpin kelompok; (8) Toleran antar sesama anggota kelompok; (9) Supportif dengan anggota kelompok yang lain; dan (10) Melakukan petunjuk guru dengan baik dan sempurna.

\section{Pelaksanaan Tindakan}

Pelaksanaan

tindakan merupakan tahapan lanjutan dari tahap rencana tindakan yang dilakukan sebelumnya, pada prosesnya peneliti melakukan tindakan nyata pembelajaran yang bertatap muka langsung dengan peserta didik, kegiatan dilakukan dengan mempedomani skenario pembelajaran yang telah dibuat sebelumnya, untuk melakukan 
penjaringan melalui observasi dan pengamatan, peneliti dibantu oleh dua kolaborator penelitian yang berperan sebagai observer yaitu satu orang kepala sekolah SDN 18/IX Muaro Jambi pemilihan kepala sekolah yaitu dengan pertimbangan sebagai atasan peneliti dan pimpinan sekolah yang mungkin hasil penelitian dapat dijadikan masukan dalam upaya meningkatkan mutu dan kualitas Pendidikan di sekolah secara keseluruhan, dan satu orang guru penjaskes SDN 104/IX Kedemangan pemilihan guru penjas tersebut dengan pertimbangan menjaga disiplin ilmu porkes yang hanya dimiliki oleh guru dengan latarbelakang Pendidikan porkes, pemilihan SDN 104/IX Kedemangan yaitu mengingat SD tersebut merupakan SD yang bersebelahan dengan SD peneliti dengan demikian dapat meminimalisir kebutuhan yang diperlukan dan lebih leluasa melakukan sejumlah pertemuan yang diperlukan.

Adapun hasil pelaksanaan siklus I dapat dilihat pada tabel 4 di bawah ini
Tabel 4. Hasil belajar peserta didik siklus I

\begin{tabular}{ccccccc}
\hline Teori & Praktik & \multicolumn{2}{c}{ Tuntas } & \multicolumn{2}{c}{ Tidak } & Rata2 \\
\cline { 5 - 6 } (Rata2) & (Rata2) & Jml & $\%$ & Jml & $\%$ & Skor \\
\hline 62,77 & 70,62 & 14 & $54 \%$ & 12 & $46 \%$ & 67,48
\end{tabular}

\section{Observasi/pengamatan}

Aktivitas guru siklus I dilakukan bersamaan dengan pelaksanaan kegiatan, pada prosesnya peneliti dibantu dua pengamat yaitu satu orang kepala sekolah SDN 18/IX Muaro Jambi dan satu orang guru penjaskes SDN 104/IX Kedemangan.

Adapun hasil pengamatan aktivitas guru siklus I dapat dilihat pada tabel 5 di bawah ini

Tabel 5. Aktivitas Guru Siklus I

\begin{tabular}{cc}
\hline Uraian & Skor \\
\hline Jumlah Skor Aktual & 41 \\
\hline Jumlah Skor Ideal & 60 \\
\hline Persentase & $\mathbf{6 8 \%}$ \\
\hline Kategori & Baik \\
\hline
\end{tabular}

Berdasarkan hasil pengamatan aktivitas guru siklus I terlihat bahwa skor aktual mendapatkan skor 41, persentase sebesar $68 \%$ yang berada pada kategori "Baik" sedangkan hasil pengamatan aktivitas peserta didik siklus I dapat dilihat pada tabel 6 di bawah ini. 
Tabel 6. Aktivitas Peserta Didik Siklus I

\begin{tabular}{cc}
\hline Uraian & Skor \\
\hline Jumlah Skor Aktual & 24 \\
\hline Jumlah Skor Ideal & 40 \\
\hline Persentase & $\mathbf{6 0 \%}$ \\
\hline Kategori & Baik \\
\hline
\end{tabular}

\section{Refleksi}

Tahap refleksi dilakukan

Bersama kolaborator penelitian untuk melakukan analisis, refleksi dan tindak lanjut atas pelaksanaan kegiatan siklus I yang dilakukan serta membicarakan hal-hal yang dianggap perlu yang mungkin tidak dimuat pada lembar observasi namun secara tidak langsung terekam pada saat pelaksanaan. Adapun hasil refleksi pada siklus I yaitu berdasarkan hasil pelaksanaan siklus I secara keseluruhan hasil belajar peserta didik mengalami peningkatan dengan signifikan yaitu ketuntasan yang semula $12 \%$ atau 3 peserta didik meningkat menjadi 14 peserta didik atau $54 \%$ pada siklus I, rata-rata kelas yang semula 55,65 yang berada pada kategori "Kurang" meningkat menjadi 67,48 yang berada pada kategori "Cukup".

Mengingat kriteria keberhasilan penelitian mempedomani kriteria ketuntasan yang ditetapkan sekolah yaitu KKM sebesar 68 secara individu dan $80 \%$ secara klasikal sedangkan pelaksanaan siklus I memperoleh ketuntasan sebesar 54\% maka penelitian dilanjutkan kembali pada siklus II dengan menempuh tahapan yang cenderung sama dengan siklus I yaitu tahap perencanaan, Tindakan, observasi dan pengamatan dan refleksi Tindakan.

Hal-hal yang perlu direvisi untuk kemudian dilakukan kembali pada siklus II diantaranya:

1. Melakukan tanya jawab seputar materi koordinasi gerak perlu ditingkatkan dengan cara memberikan ruang yang lebih leluasa kepada peserta didik dan menyajikan penjelasan dengan memberikan sejumlah contoh conton Gerakan koordinasi yang pernah dilakukan peserta didik dalam aktivitasnya sehari hari;

2. Memastikan bahwa peserta didik dapat mendengar, dan berkonsentrasi dengan baik dengan cara menguasai kelas dengan sepenuhnya yaitu melakukan kontrol disetiap kelompok peserta didik; 
3. Menjelaskan tugas kelompok, dan anggota kelompok perlu diperkuat dengan cara memastikan kesiapan peserta didik untuk mendengarkan dengan hikmat yang diakhiri dengan memastikan bahwa peserta didik memahami tugasnya dalam kelompok;

4. Memastikan bahwa peserta didik dapat berinteraksi dengan baik antara sesama anggota kelompok perlu ditingkatkan mengingat hal tersebut merupakan ciri khas model kooperatif, hal yang dilakukan yaitu melakukan penguatan keterlibatan peran anggota merupakan satu keutuhan dalam upaya mencapai keberhasilan dalam kelompok dan meningkatkan penguatan kembali bahwa kerjasama yang baik dalam kelompok akan menyumbang keberhasilan yang besar;

5. Memberikan reward berupa pujian kepada peserta didik yang berhasil perlu ditingkatkan serta memberikan support kepada peserta didik yang belum berhasil dengan menumbuhkembangkan sikap toleran antara sesama yang juga merupakan faktor pengikat dalam model kooperatif;

6. Membimbing peserta didik yang kesulitan melakukan praktik perlu diperhatikan secara konprehensif agar peserta didik dapat melakukan petunjuk lebih baik lagi;

7. Manajemen waktu perlu diperhatikan agar tidak mengambil waktu instirahat peserta didik.

\section{Siklus II}

Pelaksanaan siklus II pada prosesnya melakukan kegiatan yang cenderung sama dengan pelaksanaan siklus I yaitu menempuh tahapan rencana tindakan, melakukan tindakan, observasi dan pengamatan dan refleksi tindakan, yang membedakan pada pelaksanaan siklus II yaitu, kegiatan yang dilaksanakan pada siklus II melakukan revisi sebagaimana hal-hal yang ditemukan pada tahap refleksi tindakan siklus I yaitu dengan melakukan revisi mulai dari tahap rencana sampai ke pelaksanaan tindakan.

Sama halnya dengan siklus I, pelaksanaan siklus II dilakukan sebanyak 3 kali pertemuan yaitu pertemuan pertama $3 \times 45$ menit jam 
pelajaran dilakukan di dalam kelas kelas tepatnya hari Sabtu, 2 maret 2019, pertemuan ke dua dilakukan di lapangan olahraga SDN 18/IX Muaro Jambi tepatnya hari Sabtu, 2 maret 2019, dan pertemuan ke tiga dilakukan di dalam kelas tepatnya pada hari Sabtu, 16 maret 2019.

Adapun hasil pelaksanaan Tindakan siklus II dapat dilihat pada tabel 7 di bawah ini.

Tabel 7. Hasil belajar peserta didik siklus II

\begin{tabular}{|c|c|c|c|c|c|c|c|}
\hline \multirow{2}{*}{ Siklus } & \multirow{2}{*}{$\begin{array}{c}\text { Teori } \\
\text { (Rata2) }\end{array}$} & \multirow{2}{*}{$\begin{array}{l}\text { Praktik } \\
\text { (Rata2) }\end{array}$} & \multicolumn{2}{|c|}{ Tuntas } & \multicolumn{2}{|c|}{ Tidak } & \multirow{2}{*}{$\begin{array}{r}\text { Rata2 } \\
\text { Skor }\end{array}$} \\
\hline & & & $\mathrm{Jml}$ & $\%$ & Jml & $\%$ & \\
\hline Pra & 52,88 & 57,50 & 3 & $12 \%$ & 23 & $88 \%$ & 55,65 \\
\hline Siklus I & 62,77 & 70,62 & 14 & $54 \%$ & 12 & $46 \%$ & 67,48 \\
\hline Siklus II & 72,27 & 77,58 & 22 & $85 \%$ & 4 & $15 \%$ & 75,45 \\
\hline
\end{tabular}

Sedangkan hasil observasi dan pengamatan juga mengalami peningkatan dengan signifikan yaitu observasi aktivitas guru yang semula sebesar $68 \%$ yang berada pada kategori "Baik" meningkat menjadi $83 \%$ berada pada kategori "Sangat Baik" observasi aktivitas peserta didik yang semula $60 \%$ yang berada pada kategori "Baik" pada siklus I meningkat menjadi $83 \%$ pada siklus II yang berada pada kategori "sangat baik". hasil temuan penelitian ini sejalan dengan Suprijono, A, (2013:111) menyatakan bahwa pembelajaran dengan model kooperatif cenderung mendatangkan keuntungan lebih besar untuk mendapatkan motivasi daripada bekerja sendiri sendiri

\section{SIMPULAN}

Berdasarkan temuan hasil dan pembahasan penelitian dapat disimpulkan bahwa model kooperatif dapat meningkatkan hasil belajar koordinasi gerak peserta didik kelas III SDN 18/IX Muaro Jambi tahun ajaran 2018/2019.

Hal tersebut dilihat dari peningkatan hasil belajar peserta didik dari siklus ke siklusnya yaitu: pada kondisi pra siklus jumlah peserta didik yang tuntas hanya tiga peserta didik atau $12 \%$ meningkat pada siklus I menjadi 14 peserta didik atau 54\% dan kembali meningkat menjadi 22 peserta didik atau $85 \%$, dengan ratarata yang semula sebesar 55,65 kategori "Kurang" pda pra siklus meningkat menjadi 67,48 pada siklus 
I kategori "Cukup" dan kembali meningkat menjadi sebesar 75,45 kategori "Baik" pada siklus II.

Berdasarkan temuan hasil penelitian saran yang dapat peneliti berikan yaitu: bagi sekolah: hasil penelitian dapat menjadi masukan dalam upaya meningkatkan proses dan hasil belajar khususnya dan mutu Pendidikan umumnya, bagi guru: model kooperatif dapat menjadi alternatif solusi untuk meningkatkan hasil belajar koordinasi gerak peserta didik, bagi peserta didik: dapat terus membina kooperatif yang tepat dengan sesama dengan mengedepankan asas-asas kooperatif serta memerhatikan tradisi dan budaya yang diberlakukan.

\section{DAFTAR PUSTAKA}

Aqib, Z., \& Amrullah, A. 2018. Penelitian Tindakan Kelas Teori \& Aplikasi. Yogyakarta: ANDI OFFSET.

Arsip, N. 2019. Nilai Harian Mata Pelajaran PORKES Kelas III. Arsip.

Badan Standar Nasional Pendidikan. 2006. Standar Isi untuk Satuan Pendidikan Dasar dan Menengah; Standar Kompetensi dan Kompetensi
Dasar SD/MI. Jakarta: Badan Standar Nasional Pendidikan (BSNP).

Hamdi, M. 2018. Penelitian Tindakan Sekolah (PTS) Teori dan Praksis dalam Pendidikan. Jambi: UNJA Press.

Juniarta, P., Kanca, N., \& Putra, A. 2017. Penerapan Model Pembelajaran Kooperatif Meningkatkan Aktivitas dan Hasil Belajar Teknik Dasar Passing Bola Voli. Jurnal Pendidikan Jasmani dan Kesehatan dan Rekreasi, Volume 7(No.1), 33 - 44.

Riandini, B. K., \& Muhammad, H. N. 2013. Penerapan Model Pembelajaran Kooperatif untuk Meningkatkan Hasil Belajar Passing Bawah Melalui Permainan Bola Voli Mini. Jurnal Pendidikan Olahraga dan Kesehatan, Volume 01(No 02), 334 - 336.

Rusman. 2011. Model-model Pembelajaran. Jakarta: PT. Raja Grafindo.

Slavin. dkk. 2009. Cooperatif Learning (teori, Riset, Praktik). Bandung: Nusa Media

Suharsimi, A. 2015. Prosedur Penelitian: Suatu Pendekatan Praktik. Jakarta: Bumi Aksara. 
Suprijono, A. 2013. Cooperative

Learning Teory \& Aplikasi

Paikem. Yogyakarta: Pustaka

Pelajar. 